УДК 633.16«324:631.524.7]:631.559

06.00.00 Сельскохозяйственные науки

ЗАВИСИМОСТЬ УРОЖАЙНОСТИ И КАЧЕСТВА ЗЕРНА ОЗИМОЙ ПШЕНИЦЫ ОТ ТЕХНОЛОГИЙ ВОЗДЕЛЫВАНИЯ НА ЧЕРНОЗЕМЕ ВЫЩЕЛОЧЕННОМ В УСЛОВИЯХ ЗАПАДНОГО ПРЕДКАВКАЗЬЯ

Скоробогатова Анастасия Сергеевна

аспирант кафедры растениеводства

Нещадим Николай Николаевич

д. с - х. н., профессор кафедры растениеводства

Филипенко Николай Николаевич

аспирант кафедры растениеводства

Князева Татьяна Викторовна

доцент кафедры ботаники и кормопроизводства

ФГБОУ ВО «Кубанский государственный аграрный университет имени И.Т. Трубилина», г. Краснодар, Россия

Изучены элементы технологии выращивания озимой пшеницы сорта Антонина с применением различных фонов почвенного плодородия, норм удобрений, системы защиты растений от сорняков, вредителей и болезней. Исследования проводятся в многофакторном стационарном опыте: фактор А плодородие почвы; фактор В - система удобрений; фактор С - система защиты растений; фактор Д способы основной обработки почвы. В опыте изучали четыре модели уровней плодоро-дия почвы: $\mathrm{A}_{0}$ - исходное (естественный фон); $\mathrm{A}_{1}$ - среднее (200 кг/га $\mathrm{P}_{2} \mathrm{O}_{5}$ и 200 т/га подстилочного навоза); $\mathrm{A}_{2}$ - повышенное (дозы удваиваются); при $\mathrm{A}_{3}$ высокое (утраиваются. На основании проверенных исследований установлено, что для получения устойчивого урожая озимой пшеницы следует повышенная доза минеральных удобрений, что обеспечивает и высокие показатели качества зерна. Максимальная прибавка урожая до 37 \% было достигнута на вариантах в сравнении с экстенсивной технологией. Существенное увеличение содержания в зерне протеина с 12,8 до 15,3 \% и клейковины с 22,0 до 27,8 \% выявлено на вариантах с интенсивной технологией - тройные дозы удобрений (NPK) и применение интегрированной защиты от болезней, вредителей и сорняков. Внесение высоких доз минеральных удобрений способствует накоплению в почве и зерне азота, а также снижает содержание меди и цинка

КлючевЫе слова: СТАЦИОНАР, ПЛОДОРОДИЕ, ОЗИМАЯ ПШЕНИЦА, МИНЕРАЛЬНЫЕ УДОБРЕНИЯ, УРОЖАЙНОСТЬ, КАЧЕСТВО ЗЕРНА, ТЯЖЕЛЫЕ МЕТАЛЛЫ

DOI: 1990-4665-132-117
UDC 633.16«324:631.524.7]:631.559

Agricultural sciences

\section{DEPENDANCE OF YIELD AND GRAIN QUAL- ITY OF THE WINTER WHEAT FROM CULTI- VATION TECHNOLOGIES IN LEACHED BLACK SOIL UNDER THE CONDITIONS OF THE WESTERN PRE-CAUCASIAN REGION}

\author{
Skorobogatova Anastasiya Sergeevna \\ postgraduate of Plant Science chair
}

Neshhadim Nikolay Nikolaevich

Dr.Sci.Agr., professor of Plant Science chair

Filipenko Nikolay Nikolaevich

postgraduate of Plant Science chair

Knjazeva Tatyana Viktorovna assistant professor of Botany and Feed Production chair

Kuban State Agrarian University named after I.T.Trubilin, Krasnodar, Russia

Elements of the cultivation technology of winter wheat variety called 'Antonina' with the application of different backgrounds of soil fertility, norms of fertilizers, system of plant protection from weeds, pests and diseases were studied. The studies are conducted in a polyfactorial stationary experiment: factor A - soil fertility; factor B - system of fertilizers; factor C - plant protection system; factor D - methods of basic soil cultivation. In the experiment four models of soil fertility levels were studied: A0 - the initial (natural background); A1 - average (200 kg / ha P2O5 and $200 \mathrm{t} /$ ha of litter manure); A2 - increased (doses are doubled); when A3 - high (tripled). Based on the studies it has been established that to obtain a stable yield of winter wheat, an increased dose of mineral fertilizers should be used, which also ensures high grain quality indicators. The maximum yield increase of $37 \%$ was achieved on varieties in comparison with extensive technology. A significant increase of the protein content in the grain from 12.8 to $15.3 \%$ and gluten from 22.0 to $27.8 \%$ was found in the intensive technology - triple doses of fertilizers (NPK) and the use of integrated protection against diseases, pests and weeds. The introduction of high doses of mineral fertilizers contributes to the accumulation in the soil and grain of nitrogen, and also reduces the content of copper and zinc

Keywords: STATION, FERTILITY, WINTER WHEAT, MINERAL FERTILIZERS, YIELD, GRAIN QUALITY, HEAVY METALS 


\section{Введение}

Среди зерновых культур важнейшей является озимая пшеница - это наиболее ценная и высокоурожайная продовольственная культура $[4,5,7$, 13]. Ее ценность состоит в том, что зерно отличается высоким содержанием белка (16\%) и углеводов (80\%), она широко используется в хлебопечении, макаронной, кондитерской промышленности $[1,15]$.

В Краснодарском крае площадь посевов озимой пшеницы более 1 млн га и она занимает в структуре посевных площадей свыше 30 \% пашни $[8,10,11,13]$. Её урожайность в среднем по краю довольно стабильная, однако она существенно различается по зонам, что свидетельствует о необходимости учета при её выращивании почвенно-климатических условий, а также особенностей сорта, предшественника, системы удобрений, средств защиты растений $[2,16,17,18,21,22,30]$. В получении высоких урожаев с хорошим качеством зерна важная роль принадлежит своевременному и качественному выполнению всех технологических процессов $[6,9,12,20,23,24,26,27,29]$.

Получение высоких урожаев озимой пшеницы - основы продовольственной безопасности страны - требует тщательного учета условий выращивания и современных технологий применения химических средств земледелия, обеспечивающих экологическую безопасность окружающей среды и зерна [3, 19, 25, 32]. Для роста и развития растений, формирования урожая пшеницы необходимо оптимальное соотношение макро- и микроэлементов питания в почвенном растворе во все фазы вегетации этой культуры. Избыток азота и фосфора усиливает полегание хлебов, поражение и ржавчиной, является источником загрязнения окружающей среды $[17,18]$.

В современных условиях дальнейшее увеличение урожайности озимой пшеницы, улучшение его физико-химических и технологических качеств тесно связано с разработкой высокоэффективных зональных приемов возделывания: подбор оптимальных сортов культуры, способов обработки почвы, применением органических и минеральных удобрений и средств 
защиты растений, которые направлены на получение биологически полноценной и экологически безопасной продукции с наибольшей экономической эффективностью выращивания [3, 16, 19, 24].

Важнейшей составляющей потребительской стоимости, конкурентоспособности и агроэкологической производительности территории, является качество зерна озимой пшеницы [27]. Качество продовольственной продукции растениеводства определяется не только полноценным набором белков, но и ее безопасностью - присутствием химических веществ в приделах норм, установленных для человека и животных [14, 28]. В настоящее время в России существует несколько видов нормативов содержания минеральных веществ в биопродукции: экологотоксикологические, гигиенические, агрохимические и биогеохимические. Нестандартная продукция реализуется по более низким ценам то, от качества зерна зависит величина прибыли сельскохозяйственных предприятий. Важным также является не только содержание белка, но в связи с интенсивным применением минеральных удобрений и накопление тяжелых металлов в продуктах. В связи с этим необходимо выращивать зерно, мука из которого имела бы высокие хлебопекарные качества и соответствующую СанПин экологическую чистоту. В частности, содержание в зерне тяжелых металлов не должно превышать ПДК [3, 22, 32].

В связи с расширением сельскохозяйственной деятельности и развитием промышленного производства резко обострилась проблема ухудшения экосистем. Увеличение уровня загрязнения окружающей среды техногенными выбросами привело к тому. Что значительные площади посева сельскохозяйственных культур подвергаются воздействию токсичных веществ, вследствие чего ухудшается качество продукции, снижается продуктивность.

Повышенный уровень экотоксикантов в различных природных компонентах, с одной стороны, снижает биологическую ценность продуктов питания и кормов, а с другой - оказывает через них негативное влияние на http://ej.kubagro.ru/2017/08/pdf/117.pdf 
человека и животных. Резко снизившийся в настоящее время уровень применения удобрений часто приводит к снижению плодородия окультуренных почв и, как следствие, к загрязнению почв и растительности тяжелыми металлами. Все это обуславливает необходимость контроля содержания экотоксикантов в почве и растениеводческой продукции $[3,19]$.

Удобрения являются ведущим фактором внешней среды, оказывающим влияние на качество урожая. Минеральное питание растений улучшается при внесении научно-обоснованных доз удобрений. Поэтому оптимальные дозы удобрений разрабатывают не только на основе прибавок урожайность, но и по их действию на качество продукции. Улучшение питания способствует мобилизации физиологических ресурсов растения и повышению урожайности. Однако, для каждого сорта существует предел биологических возможностей роста урожайности. Внесение удобрений в количествах, превышающих физиологическую потребность растений, не ведет к дальнейшему увеличению урожайности и сопровождается ухудшением качества продукции. Это связано не только с повышенными дозами удобрений, но и с несбалансированностью элементов минерального питания, неправильным подбором форм макроэлементов, а также применением микроэлементов без учета содержания их в почве и требований культуры $[1,15,30,31,32]$.

Методика. На этом основании наши исследования были направлены на применения адаптивных агротехнологических приемов возделывания озимой пшеницы, обеспечивающих получение высоких урожаев с зерном высокого качества. Исследование проводилось на опытной станции Кубанского государственного аграрного университета в 2014-2016 гг.

Эксперимент проводился в многофакторном стационарном 11типольном зернотравянопропашном севообороте. Схема опыта представляет собой часть выборки из полной схемы многофакторного опыта $(4 \mathrm{x} 4 \mathrm{x} 4) \mathrm{x} 3$ и включает в себя следующие факторы: фактор А - плодородие 
почвы; фактор В - система удобрений; фактор С - система защиты растений; фактор Д - способы основной обработки почвы.

В опыте на основе существующих нормативных показателей внесением в почву удобрений изучаются четыре модели уровней плодородия почвы: $\mathrm{A}_{0}$ - исходное (естественный фон); $\mathrm{A}_{1}$ - среднее (200 кг/га $\mathrm{P}_{2} \mathrm{O}_{5}$ и 200 т/га подстилочного навоза); $\mathrm{A}_{2}$ - повышенное (дозы удваиваются); при $\mathrm{A}_{3}$ - высокое (утраиваются) на трех фонах основной обработки почвы: безотвальной, рекомендуемой, отвальной с глубоким рыхлением и на фоне нулевой обработки почвы (прямой посев и естественный уровень почвенного плодородия).

Система защиты растений (фактор С) от сорняков, вредителей и болезней имеет 4 варианта опыта: $\mathrm{C}_{0}$ - без средств защиты растений; $\mathrm{C}_{1}$ биологическая система защиты растений от вредителей и болезней; $\mathrm{C}_{2}$ химическая система защиты растений с помощью гербицидов только от сорняков, $\mathrm{C}_{3}$ - химическая система защиты растений от сорняков, вредителей и болезней с помощью пестицидов и гербицидов.

В связи с изучением нескольких факторов в схеме опыта принята специальная индексация вариантов, где первая цифра - уровень плодородия, вторая - система удобрения, третья - система защиты растений. Базовые технологии возделывания условно обозначаются: 000 - экстенсивная; 111 - беспестицидная; 222 - экологически допустимая; 333 - интенсивная.

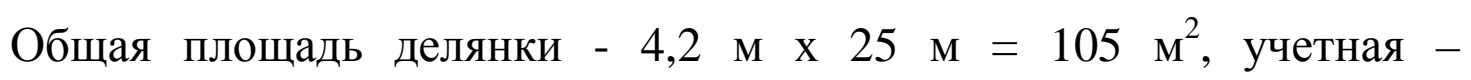
2,0 м х 17 м = 34 м². Повторность опыта - трехкратная. Предшественник подсолнечник.

В качестве контроля в схеме опыта служил вариант 000 на фоне рекомендуемой основной обработки почвы. Изучаемые факторы и их рубрикация представлены в таблице 1.

В опыте исследования проводились на фоне рекомендуемой основной обработки почвы, которая состояла из лущения на глубину 10-12 см 
дисковером фирмы Кун и вспашки на глубину 20-22 см агрегатом МТЗ1221+ПО 4-35 Кун-Мультимастер.

Таблица 1 - Схема эксперимента

\begin{tabular}{|c|c|c|c|}
\hline $\begin{array}{c}\text { Вариант } \\
\text { опыта } \\
\end{array}$ & Уровень плодородия (А) & $\begin{array}{c}\text { Система } \\
\text { удобрения (В) }\end{array}$ & $\begin{array}{c}\text { Система защиты } \\
\text { растений }(\mathrm{C})\end{array}$ \\
\hline 000 (к) & $\begin{array}{l}\text { исходный уровень плодо- } \\
\text { родия }\left(\mathrm{A}_{0}\right)\end{array}$ & $\begin{array}{l}\text { без удобрений } \\
\left(\mathrm{B}_{0}\right)\end{array}$ & $\begin{array}{l}\text { без применения средств } \\
\text { защиты растений }\left(\mathrm{C}_{0}\right)\end{array}$ \\
\hline 111 & $\begin{array}{l}\text { средний уровень плодо- } \\
\text { родия }(200 \text { т/га навоза + } \\
\left.200 \text { кг/га } \mathrm{P}_{2} \mathrm{O}_{5} ; \mathrm{A}_{1}\right)\end{array}$ & $\begin{array}{l}\text { минимальная доза } \\
\left(\mathrm{N}_{70} \mathrm{P}_{45} \mathrm{~K}_{30}+\mathrm{N}_{30}\right. \\
\text { при возобновле- } \\
\text { нии весенней ве- } \\
\left.\text { гетации; } \mathrm{B}_{1}\right)\end{array}$ & $\begin{array}{l}\text { биологическая система } \\
\text { защиты растений от } \\
\text { вредителей и болезней } \\
\left(\text { биопрепараты; } \mathrm{C}_{1} \text { ) }\right.\end{array}$ \\
\hline 222 & $\begin{array}{l}\text { повышенный уровень } \\
\text { плодородия (400 т/га } \\
\text { навоза + } 400 \text { кг/га } \mathrm{P}_{2} \mathrm{O}_{5} \text {; } \\
\left.\mathrm{A}_{2}\right)\end{array}$ & $\begin{array}{l}\text { средняя доза } \\
\left(\mathrm{N}_{140} \mathrm{P}_{90} \mathrm{~K}_{60}+\mathrm{N}_{60}\right. \\
\text { при возобновле- } \\
\text { нии весенней ве- } \\
\left.\text { гетации; } \mathrm{B}_{2}\right)\end{array}$ & $\begin{array}{l}\text { химическая система за- } \\
\text { щиты растений от сор- } \\
\text { няков }\left(\mathrm{C}_{2}\right)\end{array}$ \\
\hline 333 & $\begin{array}{l}\text { высокий уровень плодо- } \\
\text { родия (600 т/га навоза + } \\
\left.600 \text { кг/га } \mathrm{P}_{2} \mathrm{O}_{5} ; \mathrm{A}_{3}\right)\end{array}$ & $\begin{array}{l}\text { высокая доза } \\
\left(\mathrm{N}_{280} \mathrm{P}_{120} \mathrm{~K}_{80}+\mathrm{N}_{120}\right. \\
\text { при возобновле- } \\
\text { нии весенней ве- } \\
\left.\text { гетации; } \mathrm{B}_{3}\right)\end{array}$ & $\begin{array}{l}\text { химическая система за- } \\
\text { щиты растений от сор- } \\
\text { няков, вредителей и бо- } \\
\text { лезней }\left(\mathrm{C}_{3}\right)\end{array}$ \\
\hline 002 & $\begin{array}{l}\text { исходный уровень } \\
\text { плодородия }\left(\mathrm{A}_{0}\right)\end{array}$ & $\begin{array}{l}\text { без удобрений } \\
\left(\mathrm{B}_{0}\right)\end{array}$ & $\begin{array}{l}\text { химическая система за- } \\
\text { щиты растений от сор- } \\
\text { няков }\left(\mathrm{C}_{2}\right)\end{array}$ \\
\hline 020 & $\begin{array}{l}\text { исходный уровень } \\
\text { плодородия }\left(\mathrm{A}_{0}\right)\end{array}$ & $\begin{array}{l}\text { средняя доза } \\
\left(\mathrm{N}_{140} \mathrm{P}_{90} \mathrm{~K}_{60}+\mathrm{N}_{60}\right. \\
\text { при возобновле- } \\
\text { нии весенней ве- } \\
\left.\text { гетации; } \mathrm{B}_{2}\right)\end{array}$ & $\begin{array}{l}\text { без средств защиты } \\
\text { растений }\left(\mathrm{C}_{0}\right)\end{array}$ \\
\hline 022 & $\begin{array}{l}\text { исходный уровень } \\
\text { плодородия }\left(\mathrm{A}_{0}\right)\end{array}$ & $\begin{array}{l}\text { средняя доза } \\
\left(\mathrm{N}_{140} \mathrm{P}_{90} \mathrm{~K}_{60}+\mathrm{N}_{60}\right. \\
\text { при возобновле- } \\
\text { нии весенней ве- } \\
\left.\text { гетации; } \mathrm{B}_{2}\right)\end{array}$ & $\begin{array}{l}\text { химическая система за- } \\
\text { щиты растений от сор- } \\
\text { няков }\left(\mathrm{C}_{2}\right)\end{array}$ \\
\hline 200 & $\begin{array}{l}\text { повышенный уровень } \\
\text { плодородия ( } 400 \text { т/га } \\
\text { навоза + } 400 \text { кг/га } \mathrm{P}_{2} \mathrm{O}_{5} \text {; } \\
\left.\mathrm{A}_{2}\right)\end{array}$ & $\begin{array}{l}\text { без удобрений } \\
\left(\mathrm{B}_{0}\right)\end{array}$ & $\begin{array}{l}\text { без средств защиты } \\
\text { растений }\left(\mathrm{C}_{0}\right)\end{array}$ \\
\hline 202 & $\begin{array}{l}\text { повышенный уровень } \\
\text { плодородия (400 т/га } \\
\text { навоза + } 400 \text { кг/га } \mathrm{P}_{2} \mathrm{O}_{5} \text {; } \\
\left.\mathrm{A}_{2}\right)\end{array}$ & $\begin{array}{l}\text { без удобрений } \\
\left(\mathrm{B}_{0}\right)\end{array}$ & $\begin{array}{l}\text { химическая система за- } \\
\text { щиты растений от сор- } \\
\text { няков }\left(\mathrm{C}_{2}\right)\end{array}$ \\
\hline 220 & $\begin{array}{l}\text { повышенный уровень } \\
\text { плодородия (400 т/га } \\
\text { навоза + } 400 \text { кг/га } \mathrm{P}_{2} \mathrm{O}_{5} \text {; } \\
\left.\mathrm{A}_{2}\right)\end{array}$ & $\begin{array}{l}\text { средняя доза } \\
\left(\mathrm{N}_{140} \mathrm{P}_{90} \mathrm{~K}_{60}+\mathrm{N}_{60}\right. \\
\text { при возобновле- } \\
\text { нии весенней ве- } \\
\left.\text { гетации; } \mathrm{B}_{2}\right)\end{array}$ & $\begin{array}{l}\text { без средств защиты } \\
\text { растений }\left(\mathrm{C}_{0}\right)\end{array}$ \\
\hline
\end{tabular}


Использовали сорт озимой пшеницы Антонина, Кубанской селекции.

Под основную обработку почвы вносили минеральные удобрения нитроаммофоска и аммофос, с последующей заделкой их в почву дисковой бороной в следующих нормах: $\mathrm{B}_{1}-\mathrm{N}_{70} \mathrm{P}_{45} \mathrm{~K}_{30} ; \mathrm{B}_{2}-\mathrm{N}_{140} \mathrm{P}_{90} \mathrm{~K}_{60} ; \mathrm{B}_{3}-$ $\mathrm{N}_{280} \mathrm{P}_{180} \mathrm{~K}_{120}$.

Перед посевом проводилась культивация на глубину 5-6 см агрегатом МТЗ-1221+КПС-4,2+БЗСС-1,0.

Посев проводился протравленными семенами (Селест Топ - 10 л/т) в оптимальный для центральной зоны Краснодарского края срок: в 2014 году - 8 октября, в 2015 году - 6 октября сеялкой Great Plains 151C. Норму высева семян 5,0 млн. всхожих семян на 1 га, глубина заделки семян - 5-6 см. После посева почва прикатывалась кольчато-шпоровыми катками ЗККШ$6 \mathrm{~A}$.

В начале марта в фазу весеннего кущения проводили подкормку аммиачной селитрой из расчета: $\mathrm{B}_{1}-\mathrm{N}_{30} ; \mathrm{B}_{2}-\mathrm{N}_{60}$; $\mathrm{B}_{3}-\mathrm{N}_{120}$ кг д.в. на 1 га.

На вариантах с применением химической системы защиты растений $\left(\mathrm{C}_{2}\right.$ и $\left.\mathrm{C}_{3}\right)$ в конце фазы весеннего кущения проводили химическую прополку гербицидом Секатор Турбо в дозе 75 мл/га, с расходом рабочего раствоpa 200 л/га агрегатом МТ3-80+OH-600 (RAU).

Для повышения качества зерна посевы озимой пшеницы проводили подкормку на качество зерна в фазу формирования зерновки мочевиной в дозе $\mathrm{N}_{30}$ на всех вариантах, где предусмотрено внесение удобрений.

Защита растений строилась с учетом экономического порога вредоносности вредных организмов и болезней.

На опытном поле почвы представлены черноземом выщелоченным, сверхмощным легкоглинистым со средней мощностью гумусового горизонта - 147 сантиметров. Механический состав - легкоглинистый. Почвообразующими породами послужили лессовидные тяжелые суглинки с реакцией водной среды от 6,5 до 8,2. Рельеф - равнинный. Содержание гумуhttp://ej.kubagro.ru/2017/08/pdf/117.pdf 
са в пахотном слое небольшое и колеблется от 2,5 до 2,9 \%, однако, в связи с большой мощностью гумусового горизонта А + В (147 см) валовые запасы его составляют - 407 т/га, а в двухметровом слое - 457 т/га.

Наши исследования проводились в центральной зоне Краснодарского края, по температурному режиму и условиям увлажнения характеризуется умеренно - континентальным, умеренно - влажным и теплым климатом. Среднегодовая температура воздуха составляет $10,0-10,8{ }^{0} \mathrm{C}$. Среднемесячная температура самого жаркого месяца - июля - составляет 22 $24{ }^{0} \mathrm{C}$, а наиболее холодного месяца - января - $1,5-3,5{ }^{0} \mathrm{C}$. Продолжительность безморозного периода колеблется от 175 до 225 дней.

Неблагоприятное влияние на климат оказывают северо-восточные и восточные ветры, обуславливающие летом сухость и высокую температуру воздуха, а весной иссушение пахотного горизонта и пыльные бури. Преобладающими ветрами на территории являются восточные и западные.

В целом условия климата способствуют выращиванию многих сельскохозяйственных культур, в том числе и озимой пшеницы.

Урожайность озимой пшеницы находится в прямой зависимости от факторов жизни растения, которые по своей роли равнозначны и незаменимы. Под факторами жизни растения понимаются условия внешней среды, складывающиеся в течение вегетационного периода.

В среднем за годы исследования изменение урожайности зерна по вариантам опыта составили 59,7 - 81,8 ц с га, при среднем значении в опыте 73,9 ц/га (таблица 2).

Так, при среднем уровне почвенного плодородия и рекомендуемой обработке почвы, применении биозащиты от болезней и вредителей и минимальной дозе удобрений (вариант 111-беспестицидная технология) получена прибавка урожая 16,2 ц/га (27,1%), по сравнению с контролем. 
Таблица 2 - Изменение урожайности зерна озимой пшеницы сорта Антонина в зависимости от приемов выращивания, 2015 - 2016 гг.

\begin{tabular}{|c|c|c|c|c|c|}
\hline \multirow{2}{*}{ 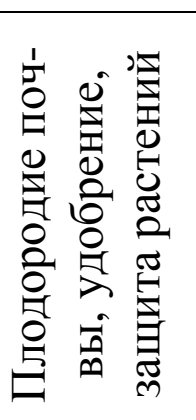 } & \multicolumn{3}{|c|}{ Урожайность зерна, ц/га } & \multicolumn{2}{|c|}{$\begin{array}{c}\text { Прибавка урожая по } \\
\text { сравнению с контро- } \\
\text { лем, }\end{array}$} \\
\hline & 2015 г. & 2016 г. & $\begin{array}{l}\text { среднее } \\
\text { за 2015- } \\
2016 \text { гг. }\end{array}$ & ц/га & $\%$ \\
\hline 000 (к) & 67,8 & 51,5 & 59,7 & - & - \\
\hline 111 & 75,6 & 76,1 & 75,9 & 16,2 & 27,1 \\
\hline 222 & 84,9 & 78,7 & 81,8 & 22,1 & 37,0 \\
\hline 333 & 80,5 & 82,9 & 81,7 & 22,0 & 36,9 \\
\hline 002 & 69,2 & 59,7 & 64,5 & 4,8 & 8,0 \\
\hline 020 & 78,5 & 63,3 & 70,9 & 11,2 & 18,8 \\
\hline 022 & 83,2 & 66,6 & 74,9 & 15,2 & 25,5 \\
\hline 200 & 74,1 & 76,2 & 75,2 & 15,5 & 26,0 \\
\hline 202 & 77,6 & 77,4 & 77,5 & 17,8 & 29,8 \\
\hline 220 & 79,0 & 76,2 & 77,6 & 17,9 & 29,9 \\
\hline $\mathrm{HCP}_{05}$ & 4,11 & 6,01 & & & \\
\hline
\end{tabular}

При повышении уровня плодородия почвы, применении средней дозы удобрений и химической системы защиты растений от сорняков (вариант 222-экологически допустимая технология) эта разница составила 22,1 ц/га $(37,0 \%)$. Внесение в три раза большего количества удобрений на фоне высокого плодородия почвы и интегрированной системы защиты растений от сорняков, вредителей и болезней (вариант 333-интенсивная технология) способствовало получению прибавки урожая зерна в 22,0 ц/га (36,9 \%).

Анализируя величину данного показателя среди промежуточных вариантов опыта, следует отметить, что в среднем наименьшей она была на варианте 002 и равнялась 64,5 ц/га, что больше контроля на 4,8 ц/га (8 \%). Применение средней дозы удобрений при естественном уровне плодородия почвы на вариантах 020 и 022 увеличивало данный показатель на 11,2 - 
15,2 ц/га (18,8 - 25,5 \%), а повышенный фон плодородия почвы, без применения удобрений (варианты 200 и 202) - на 15,5 - 17,8 ц/га $(26,0$ - 29,8 \%), по сравнению с контролем. Применение средней дозы минеральных удобрений на фоне повышенного уровня плодородия почвы (вариант 220) превышало контроль на 17,9 ц/га (29,9 \%).

Таким образом, на формирование урожая зерна озимой пшеницы оказали влияние изучаемые агротехнологии. Имеющиеся данные позволяют судить о том, что наибольшую прибавку урожая, по сравнению с контролем, отмечены на вариантах 222 - экологически допустимая технология и 333 - интенсивная технология. Интенсификация приемов выращивания озимой пшеницы существенно и достоверно влияет на урожайность зерна данной культуры.

Питание - основа жизни живого организма, в том числе и растения. От условий питания культур зависит величина урожая и его химический состав (качество). Это достигается при оптимальном сочетании света, тепла, воздуха, воды, пищи и т.д.

В связи с этим, при разработке приемов возделывания этой культуры, важно не только увеличивать урожай зерна, но и уделять должное внимание качеству выращиваемой продукции.

Качество урожая сельскохозяйственных культур тесно связано с биохимическим составом растений: содержанием белков, углеводов, жиров, витаминов и минеральных веществ. Кроме того; качество урожая оценивают специфическим для каждой культуры комплексом показателей, включающих товарные, питательные, технологические и гигиенические свойства. Внешние и физические показатели качества, такие, как цвет, масса, форма, натура зерна, учитывают при оценке товарности зерновых культур. Гигиенические показатели качества урожая оценивают по содержанию веществ, оказывающих отрицательное или вредное влияние на человека и животных при использовании в пищу или на корм растениеводчеhttp://ej.kubagro.ru/2017/08/pdf/117.pdf 
ской продукции: нитраты, нитриты, остатки пестицидов, тяжелые металлы, радионуклиды и др.

Таблица 3 - Изменение некоторых качественных показателей зерна озимой пшеницы сорта Антонина в зависимости от приемов выращивания, $2015-2016$ гг.

\begin{tabular}{|c|c|c|c|}
\hline $\begin{array}{c}\text { Плодородие } \\
\text { почвы, удобрение, } \\
\text { защита растений }\end{array}$ & Натура зерна, г/л & Протеин, \% & Клейковина, \% \\
\hline 000 (к) & 735 & 12,9 & 22,0 \\
\hline 111 & 758 & 14,0 & 26,0 \\
\hline 222 & 765 & 14,8 & 26,9 \\
\hline 333 & 798 & 15,3 & 27,8 \\
\hline 002 & 710 & 12,8 & 22,6 \\
\hline 020 & 767 & 13,8 & 24,0 \\
\hline 022 & 809 & 14,7 & 26,8 \\
\hline 200 & 771 & 13,8 & 24,1 \\
\hline 202 & 791 & 14,3 & 25,3 \\
\hline 220 & 784 & 14,9 & 26,3 \\
\hline
\end{tabular}

Из таблицы 3 видно, что при рекомендуемой обработке почвы натура зерна была наименьшей при экстенсивной технологии и составила 735 г/л. Интенсификация технологии выращивания (от 111 к 333) увеличивала данный показатель на 23 - 63 г/л (3 - 9\%), по сравнению с контролем.

Аналогичная тенденция отмечена и по содержанию протеина и клейковины в зерне озимой пшеницы. Так, наименьшее значение протеина $(12,9 \%)$ и клейковины $(22,0 \%)$ отмечено на варианте 000 при экстенсивной технологии. Последовательное повышение средств химизации земледелия от 111 к 333 при рекомендуемой обработке почвы увеличивало данный показатель протеина на $1,1-2,4 \%$ и клейковины на $4-5,8 \%$, по сравнению с контролем. 
Следует отметить, что показатели натуры зерна среди промежуточных вариантов опыта, варьировали на вариантах от 710 до 809 г/л, что меньше контроля на 25 - 74 г /л $(3-10 \%)$. Внесение средней дозы удобрений при естественном уровне плодородия почвы на вариантах 020 и 022 увеличивало данный показатель на 32 - 67 г/л (4 - 9\%), а повышенный фон плодородия почвы, без применения удобрений (варианты 200 и 202) на 36 - 56 г/л (5 - 8 \%), по сравнению с контролем. Применение средней дозы минеральных удобрений на фоне повышенного уровня плодородия почвы (вариант 220) превышало контроль на 49 г/л (7 \%). Аналогичная тенденция наблюдается при содержании протеина и клейковины.

Установлено, что повышение дозы минеральных удобрений способствует положительному изменению накоплению в зерне массовой доли азота (таблица 4). Максимальное количество этого элемента отмечено на вариантах с максимальным внесением азотных удобрений (222 и 333).

Внесение удобрений позволяет снижать содержание тяжелых металлов $(\mathrm{Cu}$ и $\mathrm{Zn})$ в зерне озимой пшеницы до допустимого уровня (таблица 4).

Таблица 4 - Влияния технологий выращивание озимой пшеницы на содержание макро- и микроэлементов, 2015 - 2016 гг.

\begin{tabular}{|c|c|c|c|c|}
\hline \multirow[t]{2}{*}{ Показатель } & \multirow[t]{2}{*}{$\begin{array}{c}\text { ИД на методы ис- } \\
\text { следований }\end{array}$} & \multirow[t]{2}{*}{$\begin{array}{c}\text { Единица } \\
\text { измерений }\end{array}$} & \multicolumn{2}{|c|}{$\begin{array}{c}\text { Значение показа- } \\
\text { телей в сухом ве- } \\
\text { ществе }\end{array}$} \\
\hline & & & полова & зерно \\
\hline \multicolumn{5}{|c|}{ Вариант опыта 000} \\
\hline Массовая доля азота & $\begin{array}{c}\text { ГОСТ } 32044.1- \\
2012 \\
\end{array}$ & $\%$ & 0,63 & 1,96 \\
\hline Массовая доля фосфора & ГОСТ 26657-97 & $\%$ & 0,41 & 1,18 \\
\hline Массовая доля калия & ГОСТ 30504-97 & $\%$ & 0,60 & 0,60 \\
\hline Цинк & ГОСТ 30692-2000 & МГ/кГ & 13,62 & 18,29 \\
\hline Медь & ГОСТ 30692-2000 & МГ/кг & 1,22 & 3,96 \\
\hline \multicolumn{5}{|c|}{ Вариант опыта 111} \\
\hline Массовая доля азота & $\begin{array}{c}\text { ГОСТ 32044.1- } \\
2012\end{array}$ & $\%$ & 0,88 & 2,52 \\
\hline Массовая доля фосфора & ГОСТ 26657-97 & $\%$ & 0,62 & 1,19 \\
\hline Массовая доля калия & ГОСТ 30504-97 & $\%$ & 0,59 & 0,60 \\
\hline Цинк & ГОСТ 30692-2000 & МГ/Кг & 18,68 & 17,61 \\
\hline Медь & ГОСТ 30692-2000 & МГ/КГ & 1,62 & 3,76 \\
\hline
\end{tabular}




\begin{tabular}{|c|c|c|c|c|}
\hline \multicolumn{5}{|c|}{ Вариант опыта 222 } \\
\hline \multirow{2}{*}{ Массовая доля азота } & $\begin{array}{c}\text { ГОСТ 32044.1- } \\
2012\end{array}$ & $\%$ & 0,87 & 2,66 \\
\hline Массовая доля фосфора & ГОСТ 26657-97 & $\%$ & 0,64 & 1,18 \\
\hline Массовая доля калия & ГОСТ 30504-97 & $\%$ & 0,62 & 0,63 \\
\hline Цинк & ГОСТ 30692-2000 & мГ/кг & 18,47 & 17,88 \\
\hline Медь & ГОСТ 30692-2000 & мГ/кг & 1,29 & 2,94 \\
\hline \multicolumn{5}{|c|}{ Вариант опыта 333 } \\
\hline Массовая доля азота & $\begin{array}{c}\text { ГОСТ 32044.1- } \\
2012\end{array}$ & $\%$ & 1,05 & 2,68 \\
\hline Массовая доля фосфора & ГОСТ 26657-97 & $\%$ & 0,71 & 1,17 \\
\hline Массовая доля калия & ГОСТ 30504-97 & $\%$ & 0,75 & 0,67 \\
\hline Цинк & ГОСТ 30692-2000 & мГ/кг & 18,44 & 17,63 \\
\hline Медь & ГОСТ 30692-2000 & мГ/кг & 1,46 & 2,45 \\
\hline
\end{tabular}

Примечание: ПДК, мг/кг: медь $(\mathrm{Cu})-10$, цинк $(\mathrm{Zn})-50$.

\section{Выводы:}

1. Внесение минеральных удобрений оказывают положительное влияние на урожай и качество зерна озимой мягкой пшеницы. Максимальная прибавка урожая до 37 \% была достигнута на вариантах 222 и 333 в сравнении с экстенсивной технологией. Существенное увеличение содержания в зерне протеина с 12,8 до 15,3 \% и клейковины с 22,0 до 27,8 \% выявлено на вариантах с интенсивной технологией - тройные дозы удобрений (NPK) и применение интегрированной защиты от болезней, вредителей и сорняков.

2. Использование повышенных доз минеральных удобрений способствует накоплению массовой доли азота в полове и зерне, а также позволяет снижать содержание тяжелых металлов.

\section{Список литературы}

1. Баршадская С.И. Урожайность и качество зерна различных сортов озимой пшеницы в зависимости от предшественника, удобрений и других приемов выращивания / С.И. Баршадская, Н.Н. Нещадим, А.А. Квашин // Политематический сетевой электронный журнал Кубанского государственного аграрного университета, - 2016. - №120. -C. $1305-1321$. 
2. Василько В.П. Плодородие орошаемых и гидроморфных пахотных земель Северного Кавказа и путь его оптимизации: учебное пособие / В.П. Василько, В.Н. Герасименко, Н.Н. Нещадим// Краснодар, 2010. - 118 с.

3. Гайдукова Н.Г. Эколого - агрохимические аспекты влияния удобрений на баланс тяжелых металлов в почве и продуктивность сельскохозяйственных культур / Н.Г. Гайдукова, И.В. Шабанова, Н.Н. Нещадим, А.В. Загорулько // Краснодар: КубГАУ, 2016. - 289 c.

4. Горпинченко К.Н. Эффективность производства зерна в Краснодарском крае / К.Н. Горпинченко // АПК: Экономика, управление. - 2007. - №10. - С. 65 - 66.

5. Горпинченко К.Н. Эффективность производства зерна в Краснодарском крае / К.Н. Горпинченко// Экономика сельского хозяйства России. - 2007.- №12. - С. 38 - 39.

6. Горпинченко К.Н. Экономическая эффективность применения перспективных агрегатов / К.Н. Горпинченко // Экономика сельского хозяйства России. - 2007. - №10. - C. $31-32$.

7. Горпинченко К.Н. Эффективность производства зерна по ресурсосберегающим технологиям / К.Н. Горпинченко // АПК: Экономика, управление, - 2007. - № 8. c. $56-58$.

8. Горпинченко К.Н. Экономическая эффективность производства и качества зерна в зависимости от приемов выращивания и технологий / К.Н. Горпинченко // Труды Кубанского государственного аграрного университета. - 2008. - №10. - С. 52 - 57.

9. Горпинченко К.Н. Уровень ресурсоемкости производства зерна в сельскохозяйственных организациях Краснодарского края / К.Н. Горпинченко // Известия Самарской государственной сельскохозяйственной академии, - 2008. - № 2. - с. 102 - 106.

10. Горпинченко К.Н. Особенности прогнозирования производства зерна / К.Н. Горпинченко // Экономика сельскохозяйственных и перерабатывающих предприятий. 2012. - №4. - C. 46 - 49.

11. Горпинченко К.Н. Уровень ресурсоемкости производства зерна в сельскохозяйственных организациях Краснодарского края/ К.Н. Горпинченко// Известия Самарской государственной сельскохозяйственной академии. - 2008. - №2. - С. 102 - 106.

12. Горпинченко К.Н. Технологический фактор научно-технического прогресса зернового производства / К.Н. Горпинченко // Известия Оренбургского государственного аграрного университета. - 2013. - №6 (116). - С. 171 - 173.

13. Горпинченко К.Н. Техническая модернизация зернового производства в Краснодарском крае/ К.Н. Горпинченко// Наука и Мир. - 2013. - №2 (2). - С. 85 - 88.

14. Горпинченко К.Н. Организационно - экономический механизм управления инновациями в зерновом производстве/ К.Н. Горпинченко// Известия Тимирязевской сельскохозяйственной академии. - 2014. - №2. - С. 134 - 141.

15. Квашин А.А. Эффективность выращивания различных сортов озимой пшеницы в условиях Западного Предкавказья/ А.А. Квашин, К.Н. Горпинченко, Н.Н. Нещадим// Политематический сетевой электронный журнал Кубанского государственного аграрного университета. - 2016. - №123. - С. 1305 - 1321.

16. Малюга Н.Г. Влияние приемов выращивания на содержание основных элементов питания, тяжелых металлов в почве и урожайность зерна озимой пшеницы в центральной зоне Краснодарского края / Н.Г. Малюга, Н.Н. Нещадим, С.В. Гаркуша, Г.Ф. Петрик// Труды Кубанского государственного аграрного университета. - 2012. №35. - С. 135 - 142 .

17. Нещадим Н.Н. Изменение процессов образования клеточной стенки стеблей ячменя и пшеницы при обработке посевов хлорхотенхлорпром (препаратом тур) / Н.Н. Нещадим, В.Г. Павлюков// Труды Кубанского государственного аграрного университета, - 1997, - № 141 (169). - с. 46 - 52. 
18. Нещадим Н.Н. Продуктивность ячменя и пшеницы при обработке посевов хлорхотенхлорпром (препаратом тур) / Н.Н. Нещадим // Труды Кубанского государственного аграрного университета, - 1978, - № 158 (186). - с. 15 - 20.

19. Нещадим Н.Н. Об экологических рисках, связанных с накоплением свинца и кадмия в зерне озимой пшеницы, выращенной на черноземе выщелоченном Западного Предкавказья / Н.Н. Нещадим, Н.Г. Гайдукова, И.В. Шабанова, И.И. Сидорова // Труды Кубанского государственного аграрного университета. 2008, - № 431, - с. 59.

20. Нещадим Н.Н. Современные проблемы качества зерна / Н.Н. Нещадим, К.Н. Горпинченко, А.А. Квашин // Труды Кубанского государственного аграрного университета. - 2012. - №35. - С. 338 - 342.

21. Нещадим Н.Н. Интегрированная защита растений (зерновые культуры) / Н.Н. Нещадим, Э.А. Пикушова, Е. Ю. Веретельник, В.С. Горковенко. - Краснодар: КубГАУ, 2014. $-277 \mathrm{c}$.

22. Нещадим Н.Н. Гербология и особенности применения гербицидов на сельскохозяйственных культурах в интегрированных системах защиты / Н.Н. Нещадим, Л.Г. Мордалева, И.В. Бедловская, Н.Н. Дмитриенко. - Краснодар: КубГАУ, - 2014. $216 \mathrm{c}$.

23. Нещадим Н.Н. Предупреждение заноса и методы ликвидации очагов карантийных сорных растений / Н.Н. Нещадим, Л.А. Шадрина, И.В. Бедловская// Международный журнал прикладных и фундаментальных исследований. - 2014. - №3 - 2. - С. $189-190$.

24. Нещадим Н.Н. Предшественник и урожайность различных сортов озимой пшеницы / Н.Н. Нещадим, А.А. Квашин, С.И. Баршадская, К.Н. Горпинченко // Актуальные вопросы научных исследований: материалы V Международной научнопрактической конференции. - Иваново. - 2016. - С. 20 - 23.

25. Нещадим Н.Н. Реакция различных сортов озимой пшеницы на условия выращивания в зоне неустойчивого увлажнения Краснодарского края/ Н.Н. Нешадим, А.А. Квашин, К.Н. Горпинченко, Н.Н. Филипенко// в ст. Актуальные направления фундаментальных и прикладных исследований. Материалы X Международной научно практической конференции: в 2 - х томах. - 2016. - С. 67 - 70.

26. Нещадим Н.Н. Предшественник и урожайность различных сортов озимой пшеницы / Н.Н. Нещадим, А.А. Квашин, С.И. Баршадская, К.Н. Горпинченко// В ст. Актуальные вопросы научных исследований сборник науч. трудов по материалам V Межд. научно - практической конференции. - 2016. - С. 20 - 23.

27. Прудников А.Г. Современные проблемы качества зерна / А.Г. Прудников, К.Н. Горпинченко, А.А. Квашин // Труды Кубанского государственного аграрного университета. - 2012. - №83. - С. 747 - 770.

28. Прудников А.Г. Концептуальный подход к управлению инновационными процессами в зерновом производстве региона / А.Г. Прудников, К.Н. Горпинченко // Политематический сетевой электронный журнал Кубанского государственного аграрного университета. - 2013. - №83. - С. 747 - 770.

29. Скоробогатова А.С. Продуктивность озимой пшеницы на черноземе выщелоченном в условиях Западного Предкавказья / А.С. Скоробогатова, Н.Н. Филипенко, М.А. Бедирханов// Политематический сетевой электронный журнал Кубанского государственного аграрного университета. - 2016. - 125 (01). - С. 724 - 737.

30. Скоробогатова А.С. Урожайность озимой пшеницы сорта Антонина в зависимости от плодородия почвы, способов основной обработки почвы/ А.С. Скоробогатова// Научное обеспечение агрокомплекса: сб. ст. по материалам IX Всеросс. конф. молодых ученых, посвященной 75-летию В.М. Шевцова. 24-26 ноября 2015 г. - Краснодар, 2016. - С. $700-701$ 
31. Штомпель Ю.А. Оценка качества почв, пути воспроизводства плодородия их и рационального использования: учебник / Ю.А. Штомпель, Н.Н. Нещадим, И.А. Лебедовский // Краснодар, - 2009. - 315 с.

32. Filgueiras A.V. Chemical scquential axtraction for metal partitioning in environmental soil samples / A.V. Filgueiras, C. Benolicho U I. Environ. Monit. - 2002. - v. 4. - P. $823-857$.

\section{References}

1. Barshadskaja S.I. Urozhajnost' i kachestvo zerna razlichnyh sortov ozimoj pshenicy v zavisimosti ot predshestvennika, udobrenij i drugih priemov vyrashhivanija / S.I. Barshadskaja, N.N. Neshhadim, A.A. Kvashin // Politematicheskij setevoj jelektronnyj zhurnal Kubanskogo gosudarstvennogo agrarnogo universiteta, - 2016. - №120. - S. 1305 - 1321.

2. Vasil'ko V.P. Plodorodie oroshaemyh i gidromorfnyh pahotnyh zemel' Severnogo Kavkaza i put' ego optimizacii: uchebnoe posobie / V.P. Vasil'ko, V.N. Gera-simenko, N.N. Neshhadim// Krasnodar, 2010. - 118 s.

3. Gajdukova N.G. Jekologo - agrohimicheskie aspekty vlijanija udobrenij na balans tjazhelyh metallov v pochve i produktivnost' sel'skohozjajstvennyh kul'tur / N.G. Gajdukova, I.V. Shabanova, N.N. Neshhadim, A.V. Zagorul'ko // Krasnodar: KubGAU, - 2016. - 289 s.

4. Gorpinchenko K.N. Jeffektivnost' proizvodstva zerna v Krasnodarskom krae / K.N. Gorpinchenko // APK: Jekonomika, upravlenie. - 2007. - №10. - S. 65 - 66.

5. Gorpinchenko K.N. Jeffektivnost' proizvodstva zerna v Krasnodarskom krae / K.N. Gorpinchenko// Jekonomika sel'skogo hozjajstva Rossii. - 2007.- №12. - S. 38 - 39.

6. Gorpinchenko K.N. Jekonomicheskaja jeffektivnost' primenenija perspektivnyh agregatov / K.N. Gorpinchenko // Jekonomika sel'skogo hozjajstva Rossii. - 2007. - №10. S. $31-32$.

7. Gorpinchenko K.N. Jeffektivnost' proizvodstva zerna po resursosberegajushhim tehnologijam / K.N. Gorpinchenko // APK: Jekonomika, upravlenie, - 2007. - № 8. - s. 56 58 .

8. Gorpinchenko K.N. Jekonomicheskaja jeffektivnost' proizvodstva i kachestva zerna v zavisimosti ot priemov vyrashhivanija i tehnologij / K.N. Gorpinchenko // Trudy Kubanskogo gosudarstvennogo agrarnogo universiteta. - 2008. - №10. - S. 52 - 57.

9. Gorpinchenko K.N. Uroven' resursoemkosti proizvodstva zerna v sel'skohozjajstvennyh organizacijah Krasnodarskogo kraja / K.N. Gorpinchenko // Izvestija Samarskoj gosudarstvennoj sel'skohozjajstvennoj akademii, - 2008. - № 2. - s. 102 - 106.

10. Gorpinchenko K.N. Osobennosti prognozirovanija proizvodstva zerna / K.N. Gorpinchenko // Jekonomika sel'skohozjajstvennyh i pererabatyvajushhih predprijatij. - 2012. №4. - S. 46 - 49.

11. Gorpinchenko K.N. Uroven' resursoemkosti proizvodstva zerna v sel'skohozjajstvennyh organizacijah Krasnodarskogo kraja/ K.N. Gorpinchenko// Izvestija Samarskoj gosudarstvennoj sel'skohozjajstvennoj akademii. - 2008. - №2. - S. 102 - 106.

12. Gorpinchenko K.N. Tehnologicheskij faktor nauchno-tehnicheskogo progressa zernovogo proizvodstva / K.N. Gorpinchenko // Izvestija Orenburgskogo gosudarstvennogo agrarnogo universiteta. - 2013. - №6 (116). - S. 171 - 173.

13. Gorpinchenko K.N. Tehnicheskaja modernizacija zernovogo proizvodstva v Krasnodarskom krae/ K.N. Gorpinchenko// Nauka i Mir. - 2013. - №2 (2). - S. 85 - 88.

14. Gorpinchenko K.N. Organizacionno - jekonomicheskij mehanizm upravlenija innovacijami v zernovom proizvodstve/ K.N. Gorpinchenko// Izvestija Timirjazevskoj sel'skohozjajstvennoj akademii. - 2014. - №2. - S. $134-141$.

15. Kvashin A.A. Jeffektivnost' vyrashhivanija razlichnyh sortov ozimoj pshenicy v uslovijah Zapadnogo Predkavkaz'ja/ A.A. Kvashin, K.N. Gorpinchenko, N.N. Neshhadim// Politematicheskij setevoj jelektronnyj zhurnal Kubanskogo gosudarstvennogo agrarnogo universiteta. - 2016. - №123. - S. 1305 - 1321. 
16. Maljuga N.G. Vlijanie priemov vyrashhivanija na soderzhanie osnovnyh jelementov pitanija, tjazhelyh metallov $\mathrm{v}$ pochve i urozhajnost' zerna ozimoj pshenicy $\mathrm{v}$ central'noj zone Krasnodarskogo kraja / N.G. Maljuga, N.N. Neshhadim, S.V. Garkusha, G.F. Petrik// Trudy Kubanskogo gosudarstvennogo agrarnogo universiteta. - 2012. - №35. - S. 135 -142 .

17. Neshhadim N.N. Izmenenie processov obrazovanija kletochnoj stenki steblej jachmenja i pshenicy pri obrabotke posevov hlorhotenhlorprom (preparatom tur) / N.N. Neshhadim, V.G. Pavljukov// Trudy Kubanskogo gosudarstvennogo agrarnogo universiteta, 1997, - № 141 (169). - s. 46 - 52.

18. Neshhadim N.N. Produktivnost' jachmenja i pshenicy pri obrabotke posevov hlorhotenhlorprom (preparatom tur) / N.N. Neshhadim // Trudy Kubanskogo gosudarstvennogo agrarnogo universiteta, - 1978, - № 158 (186). - s. 15 - 20.

19. Neshhadim N.N. Ob jekologicheskih riskah, svjazannyh s nakopleniem svinca i kadmija v zerne ozimoj pshenicy, vyrashhennoj na chernozeme vyshhelochennom Zapadnogo Predkavkaz'ja / N.N. Neshhadim, N.G. Gajdukova, I.V. Shabanova, I.I. Sidorova // Trudy Kubanskogo gosudarstvennogo agrarnogo universiteta. 2008, - № 431, - s. 59.

20. Neshhadim N.N. Sovremennye problemy kachestva zerna / N.N. Neshhadim, K.N. Gorpinchenko, A.A. Kvashin // Trudy Kubanskogo gosudarstvennogo agrarnogo universiteta. - 2012. - №35. - S. 338 - 342.

21. Neshhadim N.N. Integrirovannaja zashhita rastenij (zernovye kul'tury) / N.N. Neshhadim, Je.A. Pikushova, E. Ju. Veretel'nik, V.S. Gorkovenko. - Krasnodar: KubGAU, 2014. $-277 \mathrm{~s}$.

22. Neshhadim N.N. Gerbologija i osobennosti primenenija gerbicidov na sel'skohozjajstvennyh kul'turah v integrirovannyh sistemah zashhity / N.N. Neshhadim, L.G. Mordaleva, I.V. Bedlovskaja, N.N. Dmitrienko. - Krasnodar: KubGAU, - 2014. - 216 s.

23. Neshhadim N.N. Preduprezhdenie zanosa i metody likvidacii ochagov karantijnyh sornyh rastenij / N.N. Neshhadim, L.A. Shadrina, I.V. Bedlovskaja// Mezhdunarodnyj zhurnal prikladnyh i fundamental'nyh issledovanij. - 2014. - №3 - 2. - S. $189-190$.

24. Neshhadim N.N. Predshestvennik i urozhajnost' razlichnyh sortov ozimoj pshenicy / N.N. Neshhadim, A.A. Kvashin, S.I. Barshadskaja, K.N. Gorpinchenko // Aktual'nye voprosy nauchnyh issledovanij: materialy $\mathrm{V}$ Mezhdunarodnoj nauchno-prakticheskoj konferencii. - Ivanovo. - 2016. - S. 20 - 23.

25. Neshhadim N.N. Reakcija razlichnyh sortov ozimoj pshenicy na uslovija vyrashhivanija v zone neustojchivogo uvlazhnenija Krasnodarskogo kraja/ N.N. Neshadim, A.A. Kvashin, K.N. Gorpinchenko, N.N. Filipenko// v st. Aktual'nye napravlenija fundamental'nyh i prikladnyh issledovanij. Materialy H Mezhdunarodnoj nauchno - prakticheskoj konferencii: v $2-$ h tomah. -2016 . - S. $67-70$.

26. Neshhadim N.N. Predshestvennik i urozhajnost' razlichnyh sortov ozimoj pshenicy / N.N. Neshhadim, A.A. Kvashin, S.I. Barshadskaja, K.N. Gorpinchenko// V st. Aktual'nye voprosy nauchnyh issledovanij sbornik nauch. trudov po materialam V Mezhd. nauchno prakticheskoj konferencii. - 2016. - S. 20 - 23.

27. Prudnikov A.G. Sovremennye problemy kachestva zerna / A.G. Prudnikov, K.N. Gorpinchenko, A.A. Kvashin // Trudy Kubanskogo gosudarstvennogo agrarnogo universiteta. - 2012. - №83. - S. $747-770$.

28. Prudnikov A.G. Konceptual'nyj podhod k upravleniju innovacionnymi processami v zernovom proizvodstve regiona / A.G. Prudnikov, K.N. Gorpinchenko // Politematicheskij setevoj jelektronnyj zhurnal Kubanskogo gosudarstvennogo agrarnogo universiteta. - 2013. №83. - S. 747 - 770 .

29. Skorobogatova A.S. Produktivnost' ozimoj pshenicy na chernozeme vyshhelochennom v uslovijah Zapadnogo Predkavkaz'ja / A.S. Skorobogatova, N.N. Filipenko, M.A. Bedirhanov// Politematicheskij setevoj jelektronnyj zhurnal Kubanskogo gosudarstvennogo agrarnogo universiteta. - 2016. - 125 (01). - S. 724 - 737. 
30. Skorobogatova A.S. Urozhajnost' ozimoj pshenicy sorta Antonina v zavisimosti ot plodorodija pochvy, sposobov osnovnoj obrabotki pochvy/ A.S. Skorobogatova// Nauchnoe obespechenie agrokompleksa: sb. st. po materialam IX Vseross. konf. molodyh uchenyh, posvjashhennoj 75-letiju V.M. Shevcova. 24-26 nojabrja 2015 g. - Krasnodar, 2016. - S. 700 $-701$

31. Shtompel' Ju.A. Ocenka kachestva pochv, puti vosproizvodstva plodorodija ih i racional'nogo ispol'zovanija: uchebnik / Ju.A. Shtompel', N.N. Neshhadim, I.A. Lebedovskij // Krasnodar, - 2009. - 315 s.

32. Filgueiras A.V. Chemical scquential axtraction for metal partitioning in environmental soil samples / A.V. Filgueiras, C. Benolicho U I. Environ. Monit. - 2002. - v. 4. - P. $823-857$. 